\title{
Postharvest properties of sweet cherry fruit depending on rootstock and storage conditions
}

\author{
Ewa Dziedzic*, Jan Błaszczyk, Elz̈bieta Kaczmarczyk \\ Department of Pomology and Apiculture \\ University of Agriculture in Kraków \\ 29 Listopada 54, 31-425 Kraków, Poland
}

\begin{abstract}
'Regina' sweet cherry fruit (Prunus avium L.) harvested from trees grown on vigorous and semi-dwarfing rootstocks was stored in normal atmosphere (NA) at $8^{\circ} \mathrm{C}$ and $2^{\circ} \mathrm{C}$, and in a controlled atmosphere (CA) $3 \% \mathrm{O}_{2}+5 \% \mathrm{CO}_{2}$ at $2{ }^{\circ} \mathrm{C}$ for two weeks. At harvest time, the fruits differed in the measured quality parameters (firmness, soluble solids content - SSC, titratable acidity - TA) depending on the rootstock. The storage conditions and the rootstocks significantly influenced the fruit quality parameters after storage. Generally, reduced fruit firmness and TA, and higher SSC and SSC/TA ratio were observed at the end of the storage period. Among the rootstocks, the lowest soluble solids content was found in the fruit from trees on the vigorous F12/1 rootstock. The lower storage temperature decreased the SSC independently of the storage atmosphere composition. Firmer fruit was found in $\mathrm{CA} 2{ }^{\circ} \mathrm{C}$ compared with the other two treatments. The greatest loss of weight was found after fruit storage in NA $8^{\circ} \mathrm{C}$. The extent of fruit decay depended on the season, storage conditions and the rootstock. Storage in NA $8^{\circ} \mathrm{C}$ of the fruit grown on F12/1 rootstock resulted in the highest percentage of fungal decay. The best retention of the green colour of the peduncle was noted in CA $2{ }^{\circ} \mathrm{C}$. The findings on how the rootstocks affect sweet cherry fruit properties can be useful for sweet cherry breeding programmes, as well as for sweet cherry crop production and storage technologies.
\end{abstract}

Key words: firmness, fruit decay, soluble solids content, titratable acidity

\section{INTRODUCTION}

The world production of sweet cherries has reached more than 2.3 million metric tons and is increasing steadily due to the modern technology of tree growing. Sweet cherry is a perishable fruit; it is gathered at the stage of consumption maturity and is characterized by a high water content in the tissues, a thin skin and high intensity of respiration (Wang and Long 2014). Cherry fruits have no starch reserves, therefore the maintenance of respiration relies primarily upon organic acids (Crisosto et al. 1993). Due to the excellent taste and high nutritional value sweet cherries are highly appreciated by consumers. The time of fruit harvest and supply of fresh fruit to the market is rather short. To extend the period of fresh sweet cherry fruit consumption, the fruit can be stored for a relatively short time (up to 8 weeks), ensuring optimal storage conditions. Studies concerning new technologies of fruit storage (atmosphere, modified atmosphere packaging, air and water precooling) have been conducted for sweet cherry (Remón et al. 2000, Giacalone and Chiabrando 2013). The quality of stored fruit depends on storage conditions (temperature, atmosphere composition, humidity), which influence the physiological and biochemical

\footnotetext{
*Corresponding author.

Tel.: +48 126625232 ;

e-mail: ewa@ogr.ur.krakow.pl (E. Dziedzic).
} 
metabolism in the fruit and result in changes in fruit taste and postharvest fruit softening (Meheriuk et al. 1995, Sen et al. 2014). In modern sweet cherry cultivation, the trees are grown on dwarfing rootstocks. The type of rootstock influences fruit quality both during the vegetation period and also after storage, and is one of the most important factors contributing to the high quality of sweet cherry fruit. There have been studies demonstrating the effect of rootstocks on sweet cherry fruit during growth and ripening on the tree (Sitarek et al. 2008, Wociór 2008a, 2008b, Sitarek and Grzyb 2010), but in the available literature there is little information concerning the effect of rootstock type on the quality of sweet cherry fruit after short-time storage (Cavalheiro et al. 2005). The aim of the presented study was to evaluate the effects of the type of rootstock and storage conditions on cold storability and quality of 'Regina' sweet cherry fruit. The assessment of the influence of different rootstocks on post-storage quality of sweet cherry fruit will allow the right selection of the fruit from trees grown on the particular rootstocks.

\section{MATERIAL AND METHODS}

'Regina' sweet cherry trees were grown on the rootstocks: F12/1, 'Colt', GiSelA 5 and P-HL A at the Experimental Station of the Agricultural University, in Garlica Murowana, $10 \mathrm{~km}$ north of Kraków (Poland), $270 \mathrm{~m}$ above sea level (500' N, $19^{\circ} 56^{\prime}$ E). Trees of 'Kordia' sweet cherry provided the pollen in the orchard. Fruit was harvested at market maturity from 9-10 year-old trees on July 5, 2011 and on June 28, 2012. Five trees on each rootstock made one combination. Immediately after harvest the fruit was evaluated for firmness, soluble solids content (SSC) and titratable acidity (TA). Four samples ( $250 \mathrm{~g}$ each) of randomly picked fruit from the five trees in each combination were evaluated. Firmness was determined by using a TA 500 Texture Analyzer (Lloyd Instruments LTD.) equipped with an 8-mm probe, and the measured values were expressed in Newtons (N). Fruit SSC was determined with an Atago PR-101 digital refractometer. TA was determined by titration to $\mathrm{pH} 8.1$ with $0.1 \mathrm{~N}$ sodium hydroxide, expressing the results as the equivalent percentage of malic acid. Four fruit samples (replicates, $250 \mathrm{~g}$ each) from each treatment were stored in plastic containers for two weeks under the following conditions: normal atmosphere (NA) (RH-90\%, temperature $2^{\circ} \mathrm{C}$ ), normal atmosphere (NA) (RH-80\%, temperature $\left.8^{\circ} \mathrm{C}\right)$, and controlled atmosphere (CA) $\left(5 \% \mathrm{CO}_{2}\right.$ and
$3 \% \mathrm{O}_{2} \mathrm{RH}-90 \%$, temperature $2^{\circ} \mathrm{C}$ ). After storage, the following fruit parameters were measured: fruit firmness, SSC and TA, loss of fruit weight, changes in the peduncle colour, and the percentage of decaying fruit. The colour of peduncles was assessed by visual comparison with the Royal Horticultural Society's Colour Chart (RHS). The data were subjected to analysis of variance for a twofactorial design (rootstock and storage conditions), and the calculations were made separately for each season. The percentages of decaying fruit were transformed using the Bliss function ( $\mathrm{y}=\operatorname{arc} \sin$ $\sqrt{ } \mathrm{x})$. To determine the significance of differences between mean values, Tukey's HSD test was used at a significance level of $p \leq 0.05$.

\section{RESULTS AND DISCUSSION}

The experiment describes the results after 'Regina' sweet cherry fruits, harvested from trees growing on vigorous and dwarfing rootstocks, were stored in different atmosphere conditions for two weeks. Fruit was harvested at the commercial stage of maturity; the date of harvesting was determined based on the fruit colour. Proper harvest time is very important both for fresh, dessert fruit and for fruit to be stored. Soluble solids content varied depending on the year and rootstock (Tab. 1), and was in agreement with the observation by Kader (1999) that the minimum SSC for sweet cherry at harvest time should be $14-16 \%$. However, some authors (Drake and Elfving 2002, Serrano et al. 2009) suggest delaying the harvest time, which could enhance consumer appeal, increase fruit value, improve the quality of fruits (i.e. fruit size and SSC), and increase the yield (at the average rate of about $2 \%$ per day) (Blažková et al. 2002). Our study showed that the rootstocks significantly affected the quality features (fruit firmness, SSC, TA) of 'Regina' sweet cherry fruit at harvest (Tab. 1).

The type of rootstock influenced fruit firmness (only in the first year), SSC content and TA (Tab. 1). The fruit from trees on 'Colt' was firmer than that from trees on F12/1. Soluble solids content in the fruit from trees growing on F12/1 rootstock was low compared with the fruit from trees on the other rootstocks. The fruits from trees on the vigorous rootstock 'Colt' exhibited higher titratable acidity in the first year compared with the semidwarfing GiSelA-5 and P-HL A. These findings are consistent with those obtained by many researchers who also observed the effect of rootstock on fruit quality features. GiSelA-5 rootstock increased the 
Table 1. Fruit firmness (N), SSC (\%) and TA (\% malic acid) of 'Regina' sweet cherries at harvest as affected by rootstocks

\begin{tabular}{cccccc}
\hline Year & Rootstock & Fruit firmness & $\begin{array}{c}\text { Soluble solids } \\
\text { content (SSC) }\end{array}$ & $\begin{array}{c}\text { Titratable acidity } \\
(\text { TA })\end{array}$ & $\begin{array}{c}\text { Ratio } \\
\text { SSC/TA }\end{array}$ \\
\hline \multirow{2}{*}{2011} & F12/1 & $13.8 \pm 0.73 \mathrm{a}^{*}$ & $15.5 \pm 0.16 \mathrm{a}$ & $0.61 \pm 0.02 \mathrm{~b}$ & $25.4 \pm 0.73 \mathrm{~b}$ \\
& Colt & $17.3 \pm 3.21 \mathrm{~b}$ & $16.3 \pm 0.24 \mathrm{~b}$ & $0.66 \pm 0.02 \mathrm{c}$ & $24.7 \pm 0.84 \mathrm{a}$ \\
& GiSelA-5 & $15.9 \pm 2.25 \mathrm{ab}$ & $15.6 \pm 0.32 \mathrm{a}$ & $0.58 \pm 0.02 \mathrm{ab}$ & $26.9 \pm 0.40 \mathrm{c}$ \\
& P-HLA & $15.1 \pm 3.02 \mathrm{ab}$ & $16.6 \pm 0.24 \mathrm{~b}$ & $0.57 \pm 0.02 \mathrm{a}$ & $29.1 \pm 0.94 \mathrm{~d}$ \\
\hline \multirow{2}{*}{2012} & F12/1 & $21.9 \pm 3.82 \mathrm{a}$ & $14.8 \pm 0.24 \mathrm{a}$ & $0.74 \pm 0.03 \mathrm{~b}$ & $20.0 \pm 0.76 \mathrm{a}$ \\
& Colt & $21.9 \pm 3.18 \mathrm{a}$ & $15.4 \pm 0.33 \mathrm{~b}$ & $0.66 \pm 0.02 \mathrm{a}$ & $23.3 \pm 0.98 \mathrm{~b}$ \\
& GiSelA-5 & $20.6 \pm 2.33 \mathrm{a}$ & $15.9 \pm 0.41 \mathrm{~d}$ & $0.65 \pm 0.01 \mathrm{a}$ & $24.5 \pm 1.87 \mathrm{c}$ \\
& P-HLA & $21.8 \pm 3.29 \mathrm{a}$ & $15.7 \pm 0.24 \mathrm{c}$ & $0.65 \pm 0.01 \mathrm{a}$ & $24.2 \pm 0.50 \mathrm{c}$ \\
\hline
\end{tabular}

*Means followed by the same letter within a column, in each year, do not differ significantly at $p \leq 0.05$

SSC in sweet cherry fruit (Kankaya et al. 2008). According to Lugli and Sansavini (2008) and Rozpara (2008), the soluble solids content in the fruit from 'Regina' trees on different rootstocks ranged from $18.7 \%$ to $20.3 \%$, depending on the rootstock.

In our study, immediately after harvest, sweet cherry fruit was placed in cold storage and was stored for two weeks under three different storage conditions. Such treatment is in agreement with the majority of fruit storage experiments and has been suggested by many researchers. However, some authors report a much longer storage period for sweet cherry, i.e. 20 days in $\mathrm{CA}\left(70 \% \mathrm{O}_{2}+0 \%\right.$ $\left.\mathrm{CO}_{2}\right), 40$ days in MAP, or 80 days in CA $\left(5 \% \mathrm{O}_{2}\right.$ $+10 \% \mathrm{CO}_{2}$ ) (Jiang et al. 2002) for maintaining the good quality of fruit.

Storage conditions affected the sweet cherry fruit firmness during the cold storage period in both years (Tab. 2). In both seasons, the fruit stored in CA $2^{\circ} \mathrm{C}$ exhibited high firmness regardless of the rootstock, while NA $8^{\circ} \mathrm{C}$ decreased fruit firmness significantly. Generally, the higher fruit firmness found in CA $2^{\circ} \mathrm{C}$ is the result of slower fruit ripening in those conditions. The effect of the interaction between the rootstock and storage conditions on fruit firmness was observed in 2012 only, and the fruit from trees on P-HL A rootstock proved the advantageous effect of storage in NA $8^{\circ} \mathrm{C}$ and CA $2^{\circ} \mathrm{C}$ on fruit firmness. Cavalheiro et al. (2005) reported a significant effect of rootstock on fruit firmness, where the firmest fruit was from trees on GiSelA-5 and the softest from trees on Cab 11E. Comparing fruit firmness after the storage period with that at harvest time, we found that, generally, sweet cherries became softer after storage. Some other authors had demonstrated the ability of sweet cherries to maintain firmness for up to 8 weeks of storage (Meheriuk et al. 1995) or even increase their firmness after MA storage (Meheriuk et al. 1997, Kappel et al. 2002). The finding that high $\mathrm{CO}_{2}$ concentration and low temperature promote higher fruit firmness is also confirmed by other researchers (Jiang et al. 2002, Goliáš et al. 2006).

After the storage period, the soluble solids content in sweet cherry fruit was found changed.

Table 2. Fruit firmness (N) of 'Regina' sweet cherries after storage as affected by rootstocks and storage conditions

\begin{tabular}{|c|c|c|c|c|c|}
\hline \multirow{2}{*}{ Year } & \multirow{2}{*}{ Rootstock } & \multicolumn{3}{|c|}{ Storage conditions } & \multirow{2}{*}{ Mean for rootstock } \\
\hline & & $\mathrm{NA} 8^{\circ} \mathrm{C}$ & $\mathrm{NA} 2{ }^{\circ} \mathrm{C}$ & $\mathrm{CA} 2^{\circ} \mathrm{C}$ & \\
\hline \multirow{4}{*}{2011} & $\mathrm{~F} 12 / 1$ & $11.3 \pm 2.64 \mathrm{~ns}^{*}$ & $12.8 \pm 1.89 \mathrm{~ns}$ & $13.7 \pm 2.46 \mathrm{~ns}$ & $12.6 \pm 1.00 \mathrm{~ns}$ \\
\hline & Colt & $13.0 \pm 2.45 \mathrm{~ns}$ & $14.6 \pm 4.05 \mathrm{~ns}$ & $14.2 \pm 2.61 \mathrm{~ns}$ & $13.9 \pm 0.68 \mathrm{~ns}$ \\
\hline & GiSelA 5 & $11.6 \pm 3.44 \mathrm{~ns}$ & $14.1 \pm 3.04 \mathrm{~ns}$ & $14.8 \pm 3.12 \mathrm{~ns}$ & $13.5 \pm 0.37 \mathrm{~ns}$ \\
\hline & P-HL A & $13.6 \pm 3.39 \mathrm{~ns}$ & $14.8 \pm 2.33 \mathrm{~ns}$ & $13.7 \pm 1.44 \mathrm{~ns}$ & $14.0 \pm 0.54 \mathrm{~ns}$ \\
\hline Mean for storage & & $12.2 \pm 0.95 \mathrm{a}$ & $14.1 \pm 0.78 \mathrm{~b}$ & $14.2 \pm 0.45 \mathrm{~b}$ & \\
\hline \multirow{4}{*}{2012} & $\mathrm{~F} 12 / 1$ & $16.3 \pm 3.46 \mathrm{ab}$ & $18.1 \pm 1.43 \mathrm{a}-\mathrm{c}$ & $20.8 \pm 3.70 \mathrm{bc}$ & $18.4 \pm 1.85 \mathrm{~ns}$ \\
\hline & Colt & $19.3 \pm 4.19 \mathrm{a}-\mathrm{c}$ & $19.6 \pm 3.47 \mathrm{bc}$ & $21.6 \pm 3.22 \mathrm{c}$ & $20.2 \pm 1.02 \mathrm{~ns}$ \\
\hline & GiSelA 5 & $18.2 \pm 2.32 \mathrm{a}-\mathrm{c}$ & $18.1 \pm 2.75 \mathrm{a}-\mathrm{c}$ & $18.9 \pm 2.92 \mathrm{a}-\mathrm{c}$ & $18.9 \pm 0.36 \mathrm{~ns}$ \\
\hline & P-HL A & $14.5 \pm 2.33 \mathrm{a}$ & $19.9 \pm 2.39 \mathrm{bc}$ & $21.9 \pm 2.74 \mathrm{c}$ & $18.7 \pm 3.13 \mathrm{~ns}$ \\
\hline Mean for storage & & $17.1 \pm 1.83 \mathrm{a}$ & $18.9 \pm 0.83 \mathrm{~b}$ & $21.2 \pm 1.17 \mathrm{c}$ & \\
\hline
\end{tabular}

*Means followed by the same letter, for each storage season, do not differ significantly at $p \leq 0.05$ 
Table 3. Soluble solids content (\%) of 'Regina' sweet cherries after storage as affected by rootstocks and storage conditions

\begin{tabular}{|c|c|c|c|c|c|}
\hline \multirow{2}{*}{ Year } & \multirow{2}{*}{ Rootstock } & \multicolumn{3}{|c|}{ Storage conditions } & \multirow{2}{*}{ Mean for rootstock } \\
\hline & & $\mathrm{NA} 8^{\circ} \mathrm{C}$ & NA $2{ }^{\circ} \mathrm{C}$ & $\mathrm{CA} 2^{\circ} \mathrm{C}$ & \\
\hline \multirow{4}{*}{2011} & F12/1 & $16.6 \pm 0.24 \mathrm{bc}^{*}$ & $15.7 \pm 0.16 \mathrm{a}$ & $15.4 \pm 0.12 \mathrm{a}$ & $15.9 \pm 0.51 \mathrm{a}$ \\
\hline & Colt & $18.2 \pm 0.16 \mathrm{~d}$ & $16.6 \pm 0.26 \mathrm{~b}$ & $16.5 \pm 0.08 \mathrm{~b}$ & $17.1 \pm 0.78 \mathrm{~b}$ \\
\hline & GiSelA 5 & $17.1 \pm 0.24 \mathrm{c}$ & $15.6 \pm 0.24 \mathrm{a}$ & $15.9 \pm 0.21 \mathrm{a}$ & $16.2 \pm 0.65 \mathrm{a}$ \\
\hline & P-HL A & $18.8 \pm 0.16 \mathrm{e}$ & $17.0 \pm 0.16 \mathrm{c}$ & $17.2 \pm 0.16 \mathrm{c}$ & $17.7 \pm 0.81 \mathrm{c}$ \\
\hline Mean for storage & & $17.7 \pm 0.87 \mathrm{~b}$ & $16.2 \pm 0.59 \mathrm{a}$ & $16.3 \pm 0.67 \mathrm{a}$ & \\
\hline \multirow{4}{*}{2012} & F12/1 & $15.9 \pm 0.16 \mathrm{~ns}$ & $14.6 \pm 0.12 \mathrm{~ns}$ & $14.6 \pm 0.29 \mathrm{~ns}$ & $15.1 \pm 0.61 \mathrm{a}$ \\
\hline & Colt & $16.4 \pm 0.32 \mathrm{~ns}$ & $15.7 \pm 0.12 \mathrm{~ns}$ & $15.4 \pm 0.33 \mathrm{~ns}$ & $15.8 \pm 0.42 \mathrm{~b}$ \\
\hline & GiSelA 5 & $16.9 \pm 0.16 \mathrm{~ns}$ & $16.0 \pm 0.16 \mathrm{~ns}$ & $15.8 \pm 0.21 \mathrm{~ns}$ & $16.3 \pm 0.48 b$ \\
\hline & P-HL A & $17.0 \pm 0.33 \mathrm{~ns}$ & $15.7 \pm 0.34 \mathrm{~ns}$ & $15.7 \pm 0.14 \mathrm{~ns}$ & $16.1 \pm 0.61 \mathrm{~b}$ \\
\hline Mean for storage & & $16.6 \pm 0.44 \mathrm{~b}$ & $15.5 \pm 0.53 \mathrm{a}$ & $15.4 \pm 0.47 \mathrm{a}$ & \\
\hline
\end{tabular}

${ }^{*}$ Explanations: see Table 2

Generally, the SSC in the fruit had increased as compared with the values at harvest time (Tab. 1 and 3). Remón et al. (2003) had shown that the increased SSC in 'Burlat' sweet cherry fruit was a result of water loss during 5 days of storage. Such a relationship was also found in our investigation (Fig.1). Irrespective of the storage conditions, the low values of SSC were found for the fruit from trees on the vigorous rootstock F12/1, while the higher SSC values were observed in the fruit from trees on P-HL A. Similarly, in a study by Cavalheiro et al. (2005), another rootstock - 'TabelEdabriz', increased the SSC content in sweet cherry fruit.

Apart from the type of rootstock, the storage conditions also affected the SSC in sweet cherry. Overall, in both years, the fruit stored in NA $8^{\circ} \mathrm{C}$ exhibited higher values of SSC compared with the other treatments. The composition of air in the controlled atmosphere treatment in the experiment was $5 \% \mathrm{CO}_{2}$ and $3 \% \mathrm{O}_{2}$. Some authors (Wang and
Verstheim 2002) suggest that $\mathrm{O}_{2}$ levels for sweet cherry storage can be reduced below $10 \%$ and/ or $\mathrm{CO}_{2}$ can be increased above $15 \%$ to maintain high quality of the fruit. In turn, Tian et al. (2004) demonstrated that the SSC for sweet cherry 'Lapins' was not significantly affected by different atmosphere treatments at $1^{\circ} \mathrm{C}$. The significant effect of the interaction between the rootstocks and storage conditions on the SSC was demonstrated only in 2011, when the fruit from trees on P-HL A stored in NA $8^{\circ} \mathrm{C}$ contained the most soluble solids. The soluble solids content of $14.6-18.8 \%$ found in the fruit after storage is the level acceptable to most consumers (Kappel et al. 1996).

Titratable acidity is another fruit quality feature that is often assessed after fruit storage (Tab. 4). It was found that in both seasons, the storage conditions decreased titratable acidity of 'Regina' fruit for all the rootstocks compared with the values estimated at harvest. This observation is consistent with the statement that during storage the acidity of

Table 4. Titratable acidity (\% malic acid) of 'Regina' sweet cherries after storage as affected by rootstocks and storage conditions

\begin{tabular}{|c|c|c|c|c|c|}
\hline \multirow{2}{*}{ Year } & \multirow{2}{*}{ Rootstock } & \multicolumn{3}{|c|}{ Storage conditions } & \multirow{2}{*}{ Mean for rootstock } \\
\hline & & $\mathrm{NA} 8^{\circ} \mathrm{C}$ & $\mathrm{NA} 2{ }^{\circ} \mathrm{C}$ & $\mathrm{CA} 2{ }^{\circ} \mathrm{C}$ & \\
\hline \multirow{4}{*}{2011} & F12/1 & $0.44 \pm 0.01 \mathrm{a}^{*}$ & $0.52 \pm 0.01 \mathrm{de}$ & $0.50 \pm 0.01 \mathrm{~cd}$ & $0.49 \pm 0.03 \mathrm{a}$ \\
\hline & Colt & $0.49 \pm 0.01 \mathrm{bc}$ & $0.52 \pm 0.01 \mathrm{de}$ & $0.51 \pm 0.0 \mathrm{de}$ & $0.51 \pm 0.01 \mathrm{~b}$ \\
\hline & GiSelA 5 & $0.47 \pm 0.01 \mathrm{~b}$ & $0.49 \pm 0.01 \mathrm{bc}$ & $0.53 \pm 0.01 \mathrm{ef}$ & $0.50 \pm 0.02 \mathrm{ab}$ \\
\hline & P-HL A & $0.51 \pm 0.01 \mathrm{de}$ & $0.55 \pm 0.02 \mathrm{f}$ & $0.55 \pm 0.0 \mathrm{f}$ & $0.53 \pm 0.02 \mathrm{c}$ \\
\hline Mean for storage & & $0.48 \pm 0.03 \mathrm{a}$ & $0.52 \pm 0.02 \mathrm{~b}$ & $0.52 \pm 0.02 \mathrm{~b}$ & \\
\hline \multirow{4}{*}{2012} & $\mathrm{~F} 12 / 1$ & $0.60 \pm 0.01 \mathrm{~ns}$ & $0.53 \pm 0.02 \mathrm{~ns}$ & $0.59 \pm 0.01 \mathrm{~ns}$ & $0.58 \pm 0.03 \mathrm{~b}$ \\
\hline & Colt & $0.58 \pm 0.30 \mathrm{~ns}$ & $0.56 \pm 0.02 \mathrm{~ns}$ & $0.58 \pm 0.02 \mathrm{~ns}$ & $0.57 \pm 0.01 \mathrm{~b}$ \\
\hline & GiSelA 5 & $0.52 \pm 0.20 \mathrm{~ns}$ & $0.52 \pm 0.00 \mathrm{~ns}$ & $0.55 \pm 0.02 \mathrm{~ns}$ & $0.53 \pm 0.01 \mathrm{a}$ \\
\hline & P-HL A & $0.60 \pm 0.02 \mathrm{~ns}$ & $0.57 \pm 0.02 \mathrm{~ns}$ & $0.58 \pm 0.01 \mathrm{~ns}$ & $0.58 \pm 0.01 \mathrm{~b}$ \\
\hline Mean for storage & & $0.57 \pm 0.03 \mathrm{ab}$ & $0.55 \pm 0.02 \mathrm{a}$ & $0.58 \pm 0.02 \mathrm{~b}$ & \\
\hline
\end{tabular}

*Explanations: see Table 2 
Table 5. Soluble solids/acids ratio of 'Regina' sweet cherries after storage as affected by rootstocks and storage conditions

\begin{tabular}{lccccc}
\hline \multirow{2}{*}{ Year } & Rootstock & \multicolumn{3}{c}{ Storage conditions } \\
\cline { 3 - 5 } & & NA $8^{\circ} \mathrm{C}$ & NA 2 ${ }^{\circ} \mathrm{C}$ & CA 2 ${ }^{\circ} \mathrm{C}$ & Mean for rootstock \\
\cline { 3 - 5 } 2011 & F12/1 & $37.7 \pm 0.91 \mathrm{~b} *$ & $30.2 \pm 0.41 \mathrm{a}$ & $30.8 \pm 0.21 \mathrm{ab}$ & $32.9 \pm 3.40 \mathrm{~ns}$ \\
& Colt & $37.1 \pm 0.49 \mathrm{~b}$ & $31.9 \pm 0.61 \mathrm{ab}$ & $32.3 \pm 0.35 \mathrm{ab}$ & $33.8 \pm 2.36 \mathrm{~ns}$ \\
& GiSelA 5 & $36.4 \pm 0.88 \mathrm{~b}$ & $31.8 \pm 0.52 \mathrm{ab}$ & $30.0 \pm 0.85 \mathrm{a}$ & $32.7 \pm 2.69 \mathrm{~ns}$ \\
\hline Mean for storage & P-HL A & $36.9 \pm 0.75 \mathrm{~b}$ & $30.9 \pm 0.55 \mathrm{ab}$ & $31.3 \pm 0.60 \mathrm{ab}$ & $33.0 \pm 2.73 \mathrm{~ns}$ \\
\hline \multirow{3}{*}{2012} & & $37.0 \pm 0.47 \mathrm{~b}$ & $31.2 \pm 0.70 \mathrm{a}$ & $31.1 \pm 0.83 \mathrm{a}$ & $26.2 \pm 1.16 \mathrm{a}$ \\
& F12/1 & $26.5 \pm 0.40 \mathrm{ab}$ & $27.5 \pm 0.89 \mathrm{ab}$ & $24.7 \pm 0.77 \mathrm{a}$ & $27.6 \pm 0.74 \mathrm{a}$ \\
& Colt & $28.3 \pm 1.48 \mathrm{bc}$ & $28.0 \pm 0.68 \mathrm{bc}$ & $26.6 \pm 0.69 \mathrm{ab}$ & $30.7 \pm 1.55 \mathrm{~b}$ \\
\hline Mean for storage & GiSelA 5 & $32.5 \pm 1.44 \mathrm{~d}$ & $30.8 \pm 0.62 \mathrm{~cd}$ & $28.7 \pm 1.12 \mathrm{~b}-\mathrm{d}$ & $27.6 \pm 0.61 \mathrm{a}$ \\
\hline
\end{tabular}

${ }^{*}$ Explanations: see Table 2

fruit decreases because organic acids are involved in respiration processes (Wang and Long 2014, Wani et al. 2014). After storage, the fruit from trees on P-HL A rootstock was characterized by higher TA compared with the fruit from trees on GiSelA-5. Storing the fruit in a controlled atmosphere enables the slowing down of life processes, which in turn limits the decrease in acidity. Wang and Verstheim (2002) found significant reduction in TA in the fruit of six sweet cherry cultivars after three weeks of storage. In the 2011 season, the interaction between the rootstocks and storage conditions significantly affected the TA. The acidity of the fruit from trees on the vigorous rootstock $\mathrm{F} 12 / 1$ stored in NA $8^{\circ} \mathrm{C}$ was the lowest. The fruit stored in $\mathrm{CA} 2^{\circ} \mathrm{C}$ exhibited higher acidity than the fruit stored in NA $8^{\circ} \mathrm{C}$. In contradiction to this observation, Cavalheiro et al. (2005) had obtained higher TA for the fruit from 'Summit' cherry trees on invigorating rootstocks - Prunus avium and Cab 11E, while the fruit from those trees on 'Tabel-Edabriz' exhibited the lowest TA. By comparison, Wang and Verstheim (2002) found that the TA of the fruit of six sweet cherry cultivars stored either in $10 \% \mathrm{CO}_{2}$ or in $5 \% \mathrm{CO}_{2}$ did neither differ significantly from each other nor from the TA of the fruit stored in normal atmosphere. Meheriuk et al. $(1995,1997)$ did not find any effect of atmospheric composition on acidity changes in cherries, while other studies pointed out that low oxygen levels reduced the acid content (Jiang et al. 2002).

The ratio SSC/TA is used for qualifying optimum flavours of fruit at harvest time and after fruit storage. Comparison of these ratios indicates that the values had greatly increased after storage due to the changes in SSC and TA in the stored fruits (Tabs 1 and 5). The decrease in TA and the slight increase in SSC during fruit storage compared with the values measured at harvest resulted in such elevated SSC/TA ratios.

After storage, both the rootstocks (in one year) and the storage conditions (in two years) influenced the SSC/TA ratio significantly (Tab. 5). In normal atmosphere conditions (NA $8^{\circ} \mathrm{C}$ ), a significant increase in SSC/TA ratio was observed compared with the other two treatments. A high ratio was calculated for the fruit from trees on the semidwarfing GiSelA 5 rootstock. The interaction between the studied factors (i.e. rootstock and storage treatment) significantly affected the SSC/TA ratio in both seasons. In the discussed experiment, the sweet cherry fruit exhibited values of SSC/TA ratio higher than 30 in the first season and exceeded the value of 20 in the second season. These observations are in agreement with the statement by Kader (1999) that an acceptable SSC/ TA ratio for sweet cherry fruit should be above 20 .

The visible wrinkling of sweet cherry fruit and the wilting of the fruit peduncle was observed during the storage period. These symptoms, which were caused by the natural water loss and resulted in reduced fruit weight, were related to the storage conditions only (Fig. 1).

A greater weight loss was found for the fruit stored in NA $8^{\circ} \mathrm{C}$ than for the fruit stored in CA $2^{\circ} \mathrm{C}$. This finding is in agreement with the results obtained by other authors. For example, Rutkowski et al. (2000), Szymczak et al. (2003) for 'Kordia', Padilla-Zakour et al. (2004) for 'Hedelfingen' and 'Lapins', and Goliáš et al. (2007) for 'Techlovan', 'Summit' and 'Kordia' sweet cherry reported significant weight losses after storage in normal atmosphere. Weight loss in cherry fruits is high due 


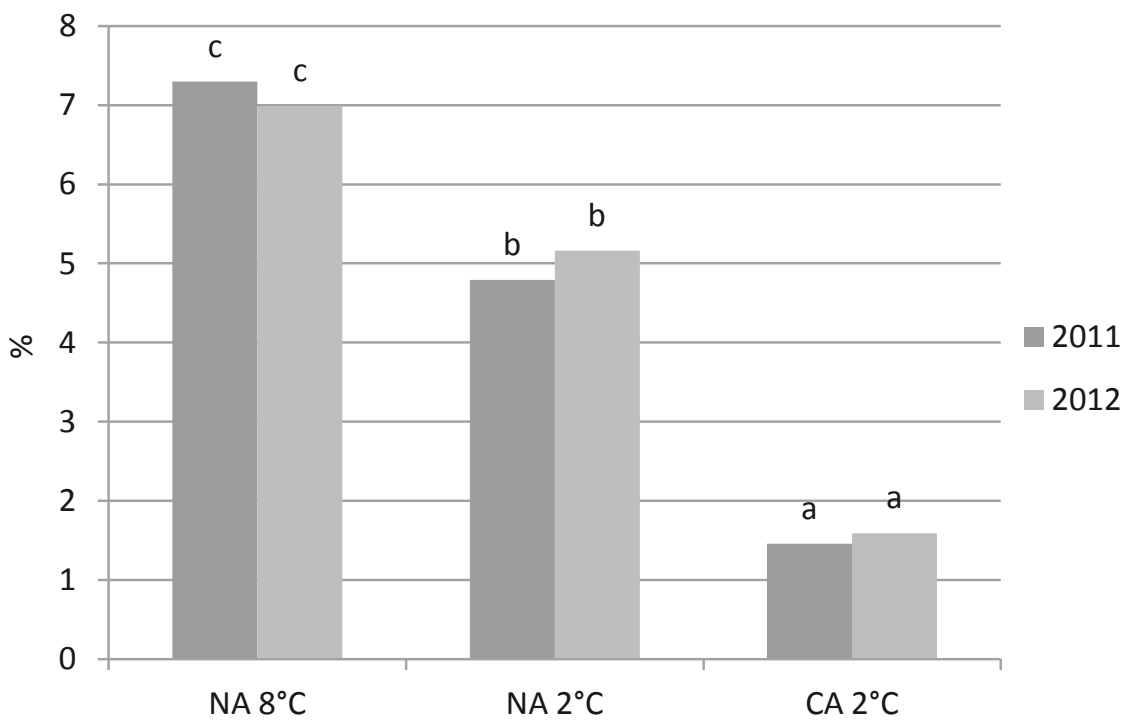

Figure 1. Natural weight loss (\%) of 'Regina' sweet cherries during storage as affected by storage conditions

to their low skin diffusion resistance (Serrano et al. 2005), and also due to a high surface/volume ratio.

One of the factors limiting successful storage of sweet cherry fruit for longer periods is the susceptibility of the fruit to fungal diseases, mainly to brown rot (Monilinia spp). The obtained results indicate that the extent of fungal decay largely depends on fruit health status at harvest time. In the first year of the study, the percentage of decaying fruit was rather high, which was the result of high air humidity noted at harvest time and probably greater amounts of fungal spores in the air and on the fruit skin (Tab. 6). In both years, the type of rootstock and the storage conditions affected the development of fungal decay symptoms.

In the first year, the fruits from trees on 'Colt' rootstock and those stored in $\mathrm{CA} 2{ }^{\circ} \mathrm{C}$ were the least infected. In the second year, the percentage of decaying fruit stayed at a very low level, not greater than $2 \%$. This finding is in agreement with the observation by Tian et al. (2004), who noted a low percentage $(1.6 \%)$ of fruit decay in a CA. Similarly, Krupa and Tomala (2000) and Tomala et al. (2003) reported that after storage CA conditions were found to have limited the percentage of 'Regina' fruit decay compared with the fruit stored in NA ( $3 \%$ and $23 \%$, respectively).

Retention of a green and not-shrivelling peduncle is one of the fruit freshness features, and is an important factor of fruit quality after sweet cherry storage. Controlled atmosphere and low temperature $\left(\mathrm{CA} 2^{\circ} \mathrm{C}\right)$ affected the retention of the green colour of the peduncle to a greater extent (higher percentage) compared with the other treatments (Tab. 7).

Our observation confirmed the finding by Drake and Elfving (2002) that the colour of the peduncle was affected by the composition of the atmosphere

Table 6. Percentage of 'Regina' sweet cherries with fungal decay symptoms after storage as affected by rootstocks and storage conditions

\begin{tabular}{|c|c|c|c|c|c|}
\hline \multirow{2}{*}{ Year } & \multirow{2}{*}{ Rootstock } & \multicolumn{3}{|c|}{ Storage conditions } & \multirow{2}{*}{ Mean for rootstock } \\
\hline & & $\mathrm{NA} 8^{\circ} \mathrm{C}$ & $\mathrm{NA} 2{ }^{\circ} \mathrm{C}$ & $\mathrm{CA} 2{ }^{\circ} \mathrm{C}$ & \\
\hline \multirow{4}{*}{2011} & $\mathrm{~F} 12 / 1$ & $16.7 \mathrm{f}^{*}$ & $9.2 \mathrm{de}$ & $8.0 \mathrm{~cd}$ & $11.3 \mathrm{~d}$ \\
\hline & Colt & $6.3 \mathrm{bc}$ & $5.4 \mathrm{~b}$ & $1.8 \mathrm{a}$ & $4.5 \mathrm{a}$ \\
\hline & GiSelA 5 & $6.7 \mathrm{bc}$ & $10.0 \mathrm{de}$ & $8.3 \mathrm{c}-\mathrm{e}$ & $8.3 \mathrm{c}$ \\
\hline & P-HL A & $11.1 \mathrm{e}$ & $2.8 \mathrm{a}$ & $7.4 \mathrm{~cd}$ & $7.1 \mathrm{~b}$ \\
\hline Mean for storage & & $10.2 \mathrm{~b}$ & $6.9 \mathrm{a}$ & $6.3 \mathrm{a}$ & \\
\hline \multirow{4}{*}{2012} & $\mathrm{~F} 12 / 1$ & $0.0 \mathrm{a}$ & $0.0 \mathrm{a}$ & $0.8 \mathrm{~b}$ & $0.3 \mathrm{a}$ \\
\hline & Colt & $0.0 \mathrm{a}$ & $1.7 \mathrm{c}$ & $0.0 \mathrm{a}$ & $0.6 \mathrm{~b}$ \\
\hline & GiSelA 5 & $0.0 \mathrm{a}$ & $0.0 \mathrm{a}$ & $0.8 \mathrm{~b}$ & $0.3 \mathrm{a}$ \\
\hline & P-HL A & $1.7 \mathrm{c}$ & $0.0 \mathrm{a}$ & $0.8 \mathrm{~b}$ & $0.8 \mathrm{c}$ \\
\hline Mean for storage & & $0.4 \mathrm{a}$ & $0.4 \mathrm{a}$ & $0.6 \mathrm{a}$ & \\
\hline
\end{tabular}

${ }^{\star}$ Explanations: see Table 2 
Table 7. Retention of the green colour by the peduncle of 'Regina' sweet cherry fruit after the storage period (\%)

\begin{tabular}{|c|c|c|c|c|c|c|}
\hline \multirow{2}{*}{ Year } & \multirow{2}{*}{ Rootstock } & \multirow{2}{*}{ At harvest } & \multicolumn{3}{|c|}{ Storage conditions } & \multirow{2}{*}{$\begin{array}{l}\text { Mean for } \\
\text { rootstock }\end{array}$} \\
\hline & & & $\mathrm{NA} 8^{\circ} \mathrm{C}$ & $\mathrm{NA} 2{ }^{\circ} \mathrm{C}$ & $\mathrm{CA} 2{ }^{\circ} \mathrm{C}$ & \\
\hline \multirow{4}{*}{2011} & F12/1 & 100 & 42.6 & 13.3 & 32.1 & 29.3 \\
\hline & Colt & 100 & 61.2 & 67.0 & 75.8 & 68.0 \\
\hline & GiSelA 5 & 100 & 57.9 & 51.1 & 73.3 & 60.8 \\
\hline & P-HL A & 100 & 61.9 & 61.5 & 60.0 & 61.1 \\
\hline \multicolumn{2}{|c|}{ Mean for storage } & & 55.9 & 48.2 & 60.3 & \\
\hline \multirow{4}{*}{2012} & $\mathrm{~F} 12 / 1$ & 100 & 54.2 & 35.8 & 67.5 & 52.5 \\
\hline & Colt & 100 & 48.3 & 26.7 & 80.0 & 51.7 \\
\hline & GiSelA 5 & 100 & 75.8 & 40.8 & 85.8 & 67.5 \\
\hline & P-HL A & 100 & 70.0 & 29.2 & 73.7 & 57.6 \\
\hline \multicolumn{2}{|c|}{ Mean for storage } & & 62.1 & 33.1 & 76.8 & \\
\hline
\end{tabular}

during storage. Also, Krupa and Tomala (2000) and Tomala et al. (2003) reported that high concentration of $\mathrm{CO}_{2}(15 \%$ or $20 \%)$ promoted the retention of the green colour of the fruit peduncle in 'Regina' sweet cherry even after six weeks of storage. Under normal atmosphere, the increasing browning of the peduncle was the quality characteristic most affected by low humidity and the loss of chlorophyll (Goliaš et al. 2006). According to Goliaš et al. (2007), temperature and humidity are the two factors that have been implicated in the browning of stems of sweet cherries.

The main reason for the discoloration of the peduncle was higher $\mathrm{O}_{2}$ concentration and higher temperature, which caused water loss from the peduncle and resulted in the browning of it (Sen et al. 2014). Rutkowski et al. (2000) had stated that the retention of green peduncles during storage was a big problem, and that the shrivelling and browning of the peduncle decreased the fruit value.

In this study, we have demonstrated how the 'Regina' sweet cherry fruit harvested from trees grown on different rootstocks differ from one another and how they retain their quality traits after storage in different conditions. Generally, the rootstocks affected the fruit quality parameters (firmness, SSC, TA) at harvest time, depending on the season. The rootstocks and the storage regime significantly influenced the fruit parameters: firmness, SSC, TA, SSC:TA ratio, fungal decay of fruit, while loss of fruit weight was affected by storage conditions only. Storage conditions decreased titratable acidity and increased the SSC of 'Regina' fruit for all the rootstocks compared with the values estimated at harvest. The information obtained in this study is not only very useful for breeding programmes, including sweet cherry cultivars and rootstocks, but also for cherry crop production and storage technologies.

\section{CONCLUSIONS}

1. Firmer fruit was found in $\mathrm{CA} 2{ }^{\circ} \mathrm{C}$ compared with the other treatments.

2. Fruits stored in NA $8^{\circ} \mathrm{C}$ exhibited the highest soluble solids content. Among the rootstocks, the lowest soluble solids content was found in the fruit from trees on the vigorous F12/1 rootstock.

3. Storage of fruits in NA $8^{\circ} \mathrm{C}$ favours higher values of SSC/TA ratio in comparison with $\mathrm{CA}$ $2^{\circ} \mathrm{C}$ conditions.

4. The highest percentage of retention of e the green colour by the peduncle was noted in CA $2^{\circ} \mathrm{C}$. The vigorous rootstock F12/1 did not promote the retention of the peduncle's green colour in comparison with the semi-dwarfing rootstocks.

\section{FUNDING}

This research was supported by the Ministry of Science and Higher Education of Poland (project number DS-3500/KSiP/2011-12).

\section{AUTHOR CONTRIBUTIONS}

E.D. and J.B. - developed the concept and designed the experiment; E.D., J.B. and E.K. - collected data and performed analysis; E.D. and J.B. - analyzed the data and wrote the paper.

\section{CONFLICT OF INTEREST}

Authors declare no conflict of interest.

\section{REFERENCES}

BlažKová J., HLušǐ̌Ková I., BlažEK J., 2002. Fruit weight, firmness and soluble solids content during ripening of Karešova.cv. sweet cherry. Hort. Sci. (Prague) 29(3): 92-98. 
Cavalheiro J.T., Santos A.A., Marques R.I., Pirra A., Silvestre A., 2005. Rootstock and storage regime influence 'Summit' cherry quality. Acta Hort. 682: 1179-1183.

Crisosto C.H., Garner D., Doyle J., Day K.R., 1993. Relationship between fruit respiration, bruising susceptibility, and temperature in sweet cherries. HortSci. 28(2): 132-135.

DRAKE S.R., ELFVING D.C., 2002. Indicators of maturity and storage quality of 'Lapins' sweet cherry. HortTechnology 12(4): 687-690.

Giacalone G., Chiabrando V., 2013. Modified atmosphere packaging of sweet cherries with biodegradable films. Inter. Food Res. J. 20(3): 12631268.

Goliáš J., LaCnÝ Z., NĚmcová A., ČAnĚK A., 2006. Release of anaerobic metabolites from intact sweet cherries in low oxygen atmospheres. Mitteilungen Klosternneuburg 56: 157-165.

GoliáŠJ., NĚMCOVÁA., ČANĚKA., KolENČíKOVÁD., 2007. Storage of sweet cherries in low oxygen and high carbon dioxide atmospheres. Hort. Sci. (Prague) 34(1): 26-34.

JiAng A.L., TIAN S.P., XU Y., 2002. Effect of controlled atmospheres with high- $\mathrm{O}_{2}$ and high $\mathrm{CO}_{2}$ concentrations on postharvest physiology and storability of 'Napoleon' sweet cherry. Acta Bot. Sin. 44(8): 925-930.

KAder A.A., 1999. Fruit maturity, ripening and quality relationships. Acta Hort. 485: 203-208.

Kankaya A., Askin M.A., Akinci-Yildrim F., Balci B., Alkan T., 2008. Evaluation of some sweet cherry cultivars on GiSelA 5 and GiSelA 6 rootstocks in Baryamic, Turkey. Acta Hort. 795: 221-225.

Kappel F., Fisher-Fleming B., Hogue E., 1996. Fruit characteristics and sensory attributes of an ideal sweet cherry. HortSci. 31(3): 443-446.

Kappel F., Toivonen P., McKenzie D.L., Stan S., 2002. Storage characteristics of new sweet cherry cultivars. HortSci. 37(1): 139-143.

Krupa T., Tomala K., 2000. Wpływ atmosfery na jakość przechowalniczą czereśni 'Regina' [Effect of atmosphere on quality of 'Regina' sweet cherry fruit]. Abstract Book XXXIX Polish Scientific Fruit Growing Conference, Skierniewice, Poland: 221222.

Lugli S., Sansavini S., 2008. Preliminary results of a cherry rootstock trial in Vignona, Italy. Acta Hort. 795: 321-326.

Meheriuk M., Girar B., Moyls A.L., Beveridge H.J.T., McKenzieD.L.,HarrisonJ., WeintrubS.,Hocking R., 1995. Modified atmosphere packaging of 'Lapins' cherry. Food Res. Int. 28: 238-244.

Meheriuk M., McKenzie D.L., Girard B., Moyls A.L., Weintraub S., Hocking R., Kopp T., 1997. Storage of 'Sweetheart' cherries in sealed plastic film. J. Food Quality 20: 189-198.
Padilla-Zakour O.I., Tandon K.S., Wargo J., 2004. Quality of modified atmosphere packaging 'Hedelfinden' and 'Lapins' sweet cherry. HortTechnology 14(3): 331-337.

Remón S., Ferrer A., Marquina P., Burgos J., Oria R., 2000. Use of modified atmospheres to prolong the postharvest life of Burlat cherries at two different degrees of ripeness. J. Sci. Food Agric. 80: $1545-$ 1552.

Remón S., Venturini M.E., Lopez-Bues P., Oria R., 2003. Burlat cherry quality after long range transport: Optimisation of packaging conditions. Innov. Food Sci. Emerq. Technol. 4: 425-434.

Rozpara E., 2008. Growth and yield of eleven sweet cherry cultivars in central Poland. Acta Hort. 795: 571-576.

Rutkowski K., Szymczak J., Grzyb Z.S., Rozpara E., 2000. Wpływ warunków przechowywania na ocenę sensoryczną czereśni odmiany 'Kordia' [Effect of storage conditions on sensory evaluation of 'Kordia' sweet cherry fruit]. Abstract Book XXXIX Polish Scientific Fruit Growing Conference, Skierniewice, Poland: 102-103.

Sen F., Oksar R. F., Golkarian M., Yaldiz S., 2014. Quality changes of different sweet cherry cultivars at various stages of the supply chain. Not. Bot. Horti. Agrobot. 42(2): 501-506.

Serrano M., Martínez-Romero D., Castillo S., Guillén F., VAlero D., 2005. The use of antifungal compounds improves the beneficial effect of MAP in sweet cherry storage. Innov. Food Sci. Emerq. Technol. 6: 115-123.

Serrano M., Diaz-Mula H.M., Zapata P.J., Castillo S., Guillén F., Martinez-Domingo R., Valverde J.M., VALERo D., 2009. Maturity stage at harvest determines the fruit quality and antioxidant potential after storage of sweet cherry cultivars. J. Agric. Food Chem. 57: 3240-3246.

Sitarek M., Grzyb Z.S., Koziński B., 2008. The influence of different rootstocks on the growth and yield of sweet cherry trees during the first four years after planting in the double row system. Acta Hort. 795: 531-536.

SitAREK M., GrZYB Z.S., 2010. Growth, productivity and fruiting of Kordia sweet cherry trees on eight clonal rootstocks. J. Fruit Ornam. Plant Res. 18(2): 169-176.

SzymczakJ.A., RutKowskiK.P., MiszczakA.,RozPara E., 2003. Sensory evaluation of 'Kordia' sweet cherry after storage. Pol. J. Food Nutr. Sci. 12/53(3): 45-49.

Tian S.P., Jiang A.L., Xu Y., Wang Y.S., 2004. Responses of physiology and quality of sweet cherry fruit to different atmospheres in storage. Food Chem. 87: 43-49.

Tomala K., Krupa T., Karbowiak A., 2003. Wpływ składu atmosfery na jakość przechowalniczą czereśni [Effect of atmosphere content on sweet 
cherry fruit quality after cool storage]. Folia Hort. Suppl. 2003/2: 206-208.

Wang L., Verstheim S., 2002. Controlled atmosphere storage of sweet cherries (Prunus avium L.). Acta Agric. Scand., Sect. B, Soil Plant Sci. 52: 136-142.

WANG Y., Long L.E., 2014. Respiration and quality responses of sweet cherry to different atmospheres during cold storage and shipping. Postharv. Biol. Technol. 92: 62-69.

Wani A.A., Singh P., Gul K., Wani M.H., Langowski H.C., 2014. Sweet cherry (Prunus avium): Critical factors affecting the composition and shelf life. Food Packaging and Shelf Life 1: 86-99.

WocIóR S., 2008a. The effect of rootstock on the growth and yielding of Regina cherry trees. Folia Hort. 20(1): 15-22.

Wociór S., 2008b. The effect of rootstock on the growth and yielding of cultivar Kordia sweet cherry trees. Acta Sci. Pol., Hortorum Cultus 7(1): 21-26.

Received January 31, 2017; accepted May 24, 2017 